\title{
Asupan vitamin, mineral, rasio asupan kalsium dan fosfor dan hubungannya dengan kepadatan mineral tulang kalkaneus wanita
}

\author{
Rita Ramayulis ${ }^{1}$, I Dewa Pramantara², Retno Pangastuti ${ }^{3}$
}

\begin{abstract}
Background: The prevalence of osteoporosis as defined by bone mineral density (BMD) > - 2.5 below the average of young women in Indonesia is not yet known; however the risk for the prevalence of osteoporosis is relatively high. Nutrients especially micronutrients have an important role in maintaining bone status. Yet, until today millions of people have micronutrient deficiency in vitamin and mineral such as calcium, zinc and beta-carotene.

Objective: To identify the relationship between intake of vitamin A, C and mineral calcium, phosphor, zinc and ratio of intake of calcium and phosphor and BMD.

Method: The study was observational with cross sectional design. Subject of the study were young women of $35-40$ years old at Health Fitness Centre of the Ministry of Health in 2007. There were as many as 102 subjects purposively taken. The dependent variable of the study was BMD and the independent variables were intake of vitamin $A, C$, and mineral calcium, phosphor, zinc and ratio of calcium and phosphor intake. The confounding variables were nutritional status, exercise, smoking, alcohol consumption, caffeine consumption, genetic, disease and medication factors. Intake data were obtained through blood record and food frequency methods. Data analysis used chi square, Fisher's exact test and independent $t$-test.

Results: The proportion of BMD of young women was 6,9\% osteoporosis, 32,4\% osteopenia and 60,8\% normal. Young women with good intake of vitamin $A$ and $C$, calcium, phosphor, zinc had average score of BMD as much as 0,35 point; 0,36 point and 0,97 point; 1,02 point; 1,26 point subsequently higher than those with less intake. Young women with ratio of good calcium and phosphor intake had BMD score as much as 1,13 point lower than those with ratio of poor calcium and phosphor intake. However, the relationship between intake of vitamin $A, C$, calcium, phosphor, zinc and ratio of calcium and phosphor intake and BMD was statistically insignificant $(p>0.05)$

Conclusion: The relationship between intake of vitamin A, C, calcium, phosphor, zinc and ratio of calcium and phosphor intake and BMD was statistically insignificant. Young women with good intake of vitamin A, C and calcium, phosphor, zinc tended to have higher score of BMD than those with poor intake.
\end{abstract}

KEY WORDS vitamin A, vitamin C, calcium, phosphor, zinc, bone mineral density

\section{PENDAHULUAN}

Angka kejadian osteoporosis pada wanita muda di Indonesia belum diketahui secara pasti, namun risiko terjadinya osteoporosis cukup tinggi. Osteoporosis didefinisikan sebagai kepadatan mineral tulang atau bone mineral density (BMD) yang lebih dari -2,5 SD di bawah rata-rata. Menurut penelitian Badan Penelitian dan Pengembangan (Litbang) Departemen Kesehatan RI tahun 2005, 1 dari 3 wanita dan 1 dari 5 pria memiliki kecenderungan menderita osteoporosis (1).

Untuk memulai pencapaian puncak BMD, faktor genetik memberikan kontribusi sebesar kurang lebih 70\% dan faktor lingkungan memberi kontribusi sebesar kurang lebih $30 \%$. Puncak BMD berhubungan dengan asupan kalsium dan latihan fisik (2). Pada penelitian longitudinal di Netherland selama 15 tahun menunjukkan bahwa latihan fisik berhubungan secara signifikan dengan BMD, namun tidak demikian dengan asupan kalsium seharihari. Hal lain yang masih menjadi masalah adalah ada atau tidaknya pengaruh asupan yang kaya semua zat gizi mikro terhadap kualitas tulang yang baik (3). Hasil penelitian di Jakarta Timur menunjukkan bahwa tidak ada hubungan yang bermakna antara asupan kalsium, vitamin $D$, konsumsi kafein, dan merokok dengan osteoporosis pada pria, sedangkan antara indeks massa tubuh (IMT) dengan osteoporosis terdapat hubungan yang bermakna. IMT subjek yang tergolong kurus berisiko mengalami osteoporosis 10 kali lebih besar dibandingkan subjek dengan IMT tergolong normal (4).

Penelitian yang dilakukan di Afrika Selatan (5) dan di UK (6) menyimpulkan bahwa untuk membentuk tulang yang sehat, tidak hanya menggunakan pendekatan kalsium, tetapi dibutuhkan zat gizi penting lainnya untuk memberikan semua kebutuhan zat gizi dan meningkatkan proses distribusi mineral. Zat-zat gizi tersebut terdiri dari vitamin dan mineral antara lain magnesium, fluor, seng, tembaga, boron, mangan, fosfor, kalium, vitamin A, D,

\footnotetext{
1 Jurusan Gizi Politeknik Kesehatan Departemen Kesehatan RI Jakarta

${ }^{2}$ Bagian Penyakit Dalam RS Dr. Sardjito, Yogyakarta

${ }^{3}$ Instalasi Gizi RS Dr. Sardjito/ Fakultas Kedokteran UGM, Yogyakarta
} 
K, dan C. Faktor lain yang juga berpengaruh terhadap pembentukan tulang yang sehat adalah rasio asupan kalsium dan fosfor (5). Fosfor di dalam tulang berada dalam perbandingan 1:2 dengan kalsium. Saat kadar fosfor menurun atau meningkat akan mempengaruhi ekskresi kalsium untuk menyeimbangkannya (7).

Saat ini diketahui bahwa kekurangan vitamin dan mineral merupakan keadaan yang biasa terjadi pada hampir setiap negara. Jutaan penduduk mengalami defisiensi tidak hanya 1 macam zat gizi, tetapi beberapa dari vitamin dan mineral seperti beta-karoten (prekursor vitamin A), seng, zat besi, dan folat (7). Konsumsi kalsium rata-rata di Indonesia hanya $254 \mathrm{mg}$ per hari dari $800 \mathrm{mg}$ per hari menurut angka kecukupan gizi yang dianjurkan (AKG) tahun 2004 (8). Dewasa ini, penelitian yang berhubungan dengan kepadatan tulang sebagian besar hanya terfokus pada asupan kalsium dan vitamin $D$ guna memaksimalkan dan meningkatkan kepadatan tulang pada wanita muda (9).

Penelitian ini bertujuan untuk melakukan kajian hubungan antara asupan vitamin $\mathrm{A}$, vitamin $\mathrm{C}$, dan asupan kalsium, fosfor, seng serta rasio asupan kalsium dan fosfor dengan kepadatan mineral tulang (BMD) pada wanita muda.

\section{BAHAN DAN METODE}

Jenis penelitian ini adalah observasional dengan rancangan penelitian cross sectional. Penelitian ini dilaksanakan di pusat kebugaran health fitness center Koperasi Bhakti Husada Departemen Kesehatan RI selama bulan Juni sampai dengan Agustus 2007.

Populasi penelitian adalah semua wanita dewasa yang berusia antara 35 sampai 40 tahun yang ada di health fitness center Koperasi Bhakti Husada Departemen Kesehatan RI dengan kriteria inklusi mempunyai indeks massa tubuh (IMT) normal dan melakukan latihan fisik teratur minimal 2 kali seminggu, selama tiga bulan terakhir. Faktor eksklusi meliputi populasi yang menderita penyakit yang berhubungan dengan osteoporosis, mempunyai faktor genetik untuk menderita osteoporosis, mengonsumsi obat-obatan yang berhubungan dengan osteoporosis, mengonsumsi rokok, makanan dan minuman perusak tulang, serta penganut vegetarian.

Besar sampel dihitung berdasarkan formula untuk satu populasi yang menggunakan jenis data kategorikal dengan skala ordinal (10). Besar sampel yang diteliti adalah 102 orang yang dihitung berdasarkan rumus besar sampel untuk satu populasi dengan tingkat kepercayaan $\mathbf{Z a}$ sebesar 95\%, prevalensi ditentukan berdasarkan survey pendahuluan yaitu $0,57, Q$ sebesar 1 dikurangi prevalensi yaitu 0,43 dan, presisi d sebesar $10 \%$. Pemilihan sampel dilakukan tanpa probabilitas secara purposive sampling, yaitu dengan menentukan subjek dalam populasi yang sesuai dengan kriteria inklusi dan eksklusi, kemudian tiap subjek diberi nomor (11).

Variabel dalam penelitian ini terdiri dari variabel terikat yaitu BMD dan variabel bebas yaitu asupan vitamin A, C, kalsium, fosfor, seng serta rasio asupan kalsium dan fosfor. Variabel pengganggu yang sudah disamakan adalah status gizi, latihan fisik, konsumsi rokok, alkohol, kafein, faktor genetik, penyakit, dan pengobatan. Kepadatan mineral tulang (BMD) yaitu status kepadatan mineral tulang yang diukur dengan alat densitometri mempergunakan metode ultrasound dengan cara mengukur tumit dalam waktu 1 menit, kemudian dikelompokkan berdasarkan kriteria kerja kelompok WHO yaitu normal sebesar $61,8 \%$, osteopeni sebesar $34,3 \%$, dan osteoporosis 3,9\%. Status gizi ditentukan berdasarkan pengukuran antropometri yang kemudian dibandingkan indikator IMT dengan kriteria underweight jika IMT kurang dari 18,5, normal jika IMT sama dengan $18,5-25$, dan overweight jika IMT lebih dari 25. Data antropometri yaitu tinggi badan diperoleh dengan mengukur tinggi badan subjek menggunakan microtoise dengan ketelitian 0,1 cm. Data berat badan diperoleh dengan menimbang menggunakan timbangan berat badan bathroomscale dengan tingkat akurasi 0,5 kg. Exercise adalah latihan fisik atau kegiatan berolahraga yang dilakukan secara rutin dan teratur, diukur dengan menggunakan kuesioner. Dikatakan rutin jika dilakukan 2 sampai 3 kali dalam selama seminggu, dikatakan teratur jika latihannya di bawah panduan instruktur.

Metode food frequency (FFQ) digunakan untuk mengetahui kebiasaan makan subjek selama tiga bulan terakhir dengan pengisian kolom sesuai dengan frekuensi (keseringan) konsumsi makanan yang termuat dalam daftar food frequency. Daftar makanan tersebut terdiri dari makanan yang merupakan sumber vitamin $A, C$, dan mineral kalsium, fosfor, dan seng. Asupan vitamin A, C, mineral kalsium, fosfor, dan seng yang diperoleh dengan menggunakan food record dan food frequency kemudian dibandingkan AKG tahun 2004 dengan klasifikasi tingkat konsumsi yang dibagi menjadi dua dengan cut off point baik jika asupan lebih atau sama dengan $80 \%$ AKG dan kurang jika asupan kurang dari 80\% AKG.

Rasio asupan kalsium dan fosfor adalah perbandingan kalsium dan fosfor yang diasup dari makanan, minuman, dan suplemen dengan menggunakan kuesioner food record dan food frequency dan dibandingkan dengan rasio kalsium dan fosfor yang tidak terpengaruh terhadap keseimbangan maupun penyerapan kalsium yaitu 0,1 2,4 banding 1 . Klasifikasinya dibagi menjadi dua yaitu baik jika rasio asupan kalsium dan fosfor 0,1-2,4: 1 dan tidak baik jika rasio tidak sama dengan 0,1-2,4 : 1 .

Pengolahan data menggunakan komputer program SPSS 14 dan nutrisurvey. Data dianalisis secara kuantitatif yang meliputi analisis univariat dan bivariat. Analisis univariat untuk mendapatkan gambaran distribusi frekuensi 
dan proporsi dari variabel asupan zat gizi dan kepadatan mineral tulang serta data demografi. Analisis bivariat untuk melihat hubungan variabel bebas yaitu asupan vitamin A, C, mineral kalsium, fosfor, seng, dan rasio asupan kalsium dan fosfor dengan kepadatan mineral tulang. Pada analisis bivariat ini, jenis uji statistik disesuaikan dengan bentuk data dari setiap variabel yaitu pengujian statistik non parametrik dan parametrik. Untuk uji non parametrik menggunakan uji chi square, uji fisher exact dan uji continuity correction. Untuk uji parametrik digunakan uji korelasi pearson bagi data yang berdistribusi normal dan uji korelasi spearman pada data yang berdistribusi tidak normal. Sedangkan untuk uji perbedaan digunakan uji t-independent.

\section{HASIL DAN BAHASAN}

\section{Analisis univariat}

Asupan vitamin dan mineral terdiri dari asupan vitamin $A$ dan $C$ serta kalsium, fosfor, seng, dan rasio asupan kalsium dan fosfor. Asupan fosfor dan seng mempunyai distribusi normal, sedangkan untuk asupan vitamin $A, C$, dan mineral kalsium, serta rasio asupan kalsium dan fosfor mempunyai distribusi tidak normal.

Median asupan vitamin A, vitamin C, kalsium, serta rasio asupan kalsium dan fosfor pada subjek berturut-turut sebesar 517,25 $\mu \mathrm{g}$ RE (103,45\% AKG), 52 mg (69,33\% AKG), 345,5 g (43,19\% AKG), serta 0,5 : 1 (AKG = 0,1$2,4: 1$ ). Sebanyak $63,7 \%$ subjek (65 orang) mempunyai asupan vitamin A yang baik, 57,8\% subjek (59 orang) mempunyai asupan vitamin $\mathrm{C}$ yang kurang, 95,1\% subjek (97 orang) mempunyai asupan kalsium yang kurang, serta
Tabel 1. Distribusi makanan yang dikonsumsi subjek lebih dari satu kali seminggu

\begin{tabular}{ll}
\hline Sumber makanan & \multicolumn{1}{c}{ Dikonsumsi lebih dari 1 x seminggu } \\
\hline Sumber vitamin A & $\begin{array}{l}\text { Merah telur, susu bubuk, wortel, tomat, } \\
\text { pepaya, mentega/margarin }\end{array}$ \\
Sumber vitamin C & $\begin{array}{l}\text { Kentang, sawi, bayam, cabe rawit, cabe } \\
\text { hijau, cabe merah, kembang kol, jeruk } \\
\text { manis, pepaya, tomat }\end{array}$ \\
Sumber kalsium & $\begin{array}{l}\text { Susu bubuk, bayam, kangkung } \\
\text { Sumber fosfor }\end{array}$ \\
Tempe, susu kedelai \\
\hline
\end{tabular}

$98 \%$ subjek (100 orang) mempunyai rasio asupan kalsium dan fosfor yang baik.

Rata-rata asupan fosfor subjek adalah $643,4 \mathrm{~g}$ $(107,23 \%$ AKG) dengan standar deviasi sebesar 168,9 g, dan sebanyak $81,4 \%$ subjek (83 orang) mempunyai asupan fosfor yang baik. Rata-rata asupan seng subjek adalah 5,1 mg (52,5\% AKG) dengan standar deviasi sebesar $1,47 \mathrm{mg}$ dan sebanyak $96,1 \%$ subjek (98 orang) mempunyai asupan seng yang kurang.

Berdasarkan metode food frequency, diperoleh bahwa dari 21 jenis makanan sumber vitamin A, 6 jenis di antaranya dikonsumsi oleh sebagian besar subjek lebih dari 1 x seminggu dan diantara 26 jenis makanan sumber vitamin $\mathrm{C}$, sebanyak 10 jenis makanan yang dikonsumsi subjek lebih dari 1 x seminggu. Dari 16 jenis makanan sumber kalsium, 3 jenis saja yang dikonsumsi oleh sebagian besar subjek lebih dari $1 \mathrm{x}$ seminggu. Diantara 15 jenis makanan sumber fosfor, 2 jenis yang dikonsumsi oleh sebagian besar subjek lebih dari $1 \mathrm{x}$ seminggu. Dari 8 jenis makanan sumber seng hanya 1 jenis saja yang

Tabel 2. Hubungan asupan vitamin A, vitamin C, kalsium, fosfor, rasio asupan kalsium dan fosfor dengan BMD

\begin{tabular}{|c|c|c|c|c|c|c|c|c|c|}
\hline \multirow{3}{*}{ Variabel } & \multicolumn{4}{|c|}{ BMD } & \multirow{2}{*}{\multicolumn{2}{|c|}{ Total }} & \multirow{3}{*}{$\mathbf{p}$} & \multirow{3}{*}{$\mathbf{R P}$} & \multirow{3}{*}{ IK $95 \%$} \\
\hline & \multicolumn{2}{|c|}{$\begin{array}{c}\text { Normal } \\
(n=62)\end{array}$} & \multicolumn{2}{|c|}{$\begin{array}{c}\text { Tidak normal } \\
(n=40)\end{array}$} & & & & & \\
\hline & $\mathbf{n}$ & $\%$ & $\mathbf{n}$ & $\%$ & $\mathbf{n}$ & $\%$ & & & \\
\hline \multicolumn{10}{|l|}{ Asupan vitamin $A^{a}$} \\
\hline Baik & 39 & 60,0 & 26 & 40,0 & 65 & 100 & \multirow[t]{2}{*}{0,76} & \multirow[t]{2}{*}{0,80} & $0,35-$ \\
\hline Kurang & 23 & 62,2 & 14 & 37,8 & 37 & 100 & & & 1,84 \\
\hline \multicolumn{10}{|l|}{ Asupan vitamin $\mathrm{C}^{\mathrm{a}}$} \\
\hline Baik & 26 & 60,5 & 17 & 39,5 & 43 & 100 & \multirow[t]{2}{*}{0,93} & \multirow[t]{2}{*}{1,13} & $0,51-$ \\
\hline Kurang & 36 & 61,0 & 23 & 39,0 & 59 & 100 & & & 2,50 \\
\hline \multicolumn{10}{|l|}{ Asupan kalsiumb } \\
\hline Baik & 5 & 100 & 0 & 0 & 5 & 100 & \multirow[t]{2}{*}{0,08} & \multirow[t]{2}{*}{-} & \multirow[t]{2}{*}{-} \\
\hline Kurang & 57 & 58,8 & 40 & 41,2 & 97 & 100 & & & \\
\hline \multicolumn{10}{|l|}{ Asupan fosfor ${ }^{a}$} \\
\hline Baik & 53 & 63,9 & 30 & 36,1 & 83 & 100 & \multirow[t]{2}{*}{0,39} & \multirow[t]{2}{*}{1,77} & $0,65-$ \\
\hline Kurang & 9 & 47,4 & 10 & 52,6 & 19 & 100 & & & 4,83 \\
\hline \multicolumn{10}{|l|}{ Asupan seng ${ }^{b}$} \\
\hline Baik & 3 & 75,0 & 1 & 25,0 & 4 & 100 & \multirow[t]{2}{*}{0,64} & \multirow[t]{2}{*}{2,16} & $0,22-$ \\
\hline Kurang & 59 & 60,2 & 39 & 39,8 & 98 & 100 & & & 21,49 \\
\hline \multicolumn{10}{|c|}{ Rasio asupan kalsium dan fosforb } \\
\hline Baik & 60 & 60 & 40 & 40 & 100 & 100 & \multirow[t]{2}{*}{0,51} & \multirow[t]{2}{*}{-} & \\
\hline Kurang & 2 & 100 & 0 & 0 & 2 & 100 & & & \\
\hline
\end{tabular}

Keterangan : ${ }^{a}$ uji chi square

${ }^{\mathrm{b}}$ uji fisher's exact 
sebagian besar dikonsumsi oleh subjek lebih dari $1 \mathrm{x}$ seminggu (Tabel 1).

\section{Analisis bivariat}

Hasil analisis bivariat hubungan antara asupan vitamin A, vitamin C, kalsium, fosfor, rasio asupan kalsium dan fosfor dengan BMD dapat dilihat pada Tabel 2.

\section{Hubungan antara asupan vitamin A dengan densitas mineral tulang (BMD)}

Sebanyak $62,2 \%$ subjek dengan asupan vitamin $A$ kurang memiliki densitas mineral tulang atau bone mineral density (BMD) normal, sedangkan hanya sebanyak 60,0\% subjek dengan asupan vitamin A baik yang memiliki BMD normal. Namun demikian berdasarkan uji continuity correction, hubungan antara asupan vitamin A dengan BMD tidak signifikan ( $p>0,05)$. Hasil analisis menunjukkan nilai ratio prevalence (RP) adalah 0,80 dengan interval kepercayaan (IK) 95\% = 0,35 - 1,840 (Tabel 2). Hal ini berarti bahwa asupan vitamin A tidak dapat disimpulkan sebagai faktor risiko terjadinya penurunan BMD.

Berdasarkan uji korelasi spearman, tidak terdapat hubungan antara asupan vitamin A dengan $\operatorname{BMD}(p=0,624)$. Dilihat dari rata-rata skor BMD pada kedua kelompok, subjek dengan asupan vitamin A baik memiliki skor BMD sebesar 0,35 poin lebih tinggi dibanding subjek dengan asupan vitamin A kurang. Namun demikian berdasarkan hasil uji t perbedaan ini tidak signifikan $(p>0,05)$.

Vitamin A berperan penting dalam proses remodeling tulang sebab vitamin $\mathrm{A}$ (asam retinoat) merupakan reseptor dari osteoblas dan osteoklas. Kekurangan vitamin A dapat menyebabkan terjadinya perubahan bentuk tulang, namun kelebihan asupan vitamin $\mathrm{A}$ (retinol) atau tingginya retinol serum dihubungkan dengan BMD yang rendah dan peningkatan risiko patah tulang (12). Asupan vitamin A yang sesuai dengan angka kecukupan gizi (AKG) yaitu sebesar $500 \mu \mathrm{g}$ RE dapat menjaga dan memelihara puncak kepadatan tulang.

Hubungan yang tidak signifikan antara asupan vitamin A dengan BMD dapat disebabkan oleh pengaruh dari asupan zat gizi lain yang tidak memenuhi AKG. Proses normal perkembangan dan mineralisasi tulang memerlukan vitamin $\mathrm{A}$ dan $\mathrm{C}$ yang cukup. Pada penelitian ini, sebagian besar subjek mempunyai asupan vitamin $\mathrm{C}$ yang kurang.

Asupan vitamin A yang berlebihan juga tidak baik karena berhubungan dengan penurunan BMD dan peningkatan risiko patah tulang paha (13). Hasil penelitian di Denmark yang menggunakan analisis cross-sectional dan longitudinal juga menunjukkan bahwa asupan vitamin A yang tinggi yaitu lebih dari $1500 \mu \mathrm{g}$ RE dihubungkan dengan peningkatan risiko patah tulang sebanyak 2 kali lipat (14).
Pada penelitian ini, ditemukan 4 orang subjek mempunyai asupan vitamin A lebih dari $1500 \mu \mathrm{g} R$ dan 3 di antaranya memiliki BMD tidak normal serta 1 orang memiliki BMD normal. Dari data hasil analisis zat gizi dijelaskan bahwa subjek yang mempunyai asupan vitamin A lebih dari $1500 \mu \mathrm{g}$ R, tetapi memiliki BMD normal didukung oleh baiknya asupan kalsium yang baik yaitu sebesar $156 \%$ sedangkan 3 subjek lain mempunyai asupan kalsium yang kurang, masing-masing sebesar $76 \%, 55 \%$, dan $78 \%$.

Hal ini sejalan dengan penelitian yang dilakukan di Swedia pada tikus yang dilaporkan bahwa asupan vitamin A yang tinggi dapat meningkatkan hambatan pertumbuhan tulang pada tikus (15). Demikian pula pada penelitian di Swedia yang melaporkan bahwa asupan vitamin A yang tinggi pada wanita yaitu lebih dari $3 \mathrm{mg}$ per hari dapat menyebabkan risiko fraktura $48 \%$ lebih tinggi dibandingkan dengan wanita dengan asupan vitamin A kurang dari 1,25 mg per hari (16). Pada penelitian ini, 2 orang subjek dengan asupan vitamin A lebih dari $3 \mathrm{mg}$ per hari mempunyai BMD yang tidak normal dengan skor -2,1 dan -1,9.

\section{Hubungan antara asupan vitamin $\mathrm{C}$ dengan densitas mineral tulang (BMD)}

Sebanyak $61,0 \%$ subjek dengan asupan vitamin C kurang memiliki BMD normal, sedangkan subjek dengan asupan vitamin $\mathrm{C}$ baik hanya $60,5 \%$ yang memiliki BMD normal. Namun demikian, berdasarkan hasil uji continuity correction, hubungan antara asupan vitamin $\mathrm{C}$ dengan BMD tidak signifikan ( $p>0,05)$. Hasil analisis menunjukkan nilai RP adalah 1,13 dengan IK 95\% melewati angka 1 yaitu 0,35-1,840 (Tabel 2). Hal ini berarti bahwa asupan vitamin $\mathrm{C}$ tidak dapat disimpulkan sebagai faktor risiko terjadinya penurunan BMD.

Berdasarkan uji korelasi spearman, tidak terdapat hubungan antara asupan vitamin $C$ dengan $\operatorname{BMD}(p=0,210)$. Rata-rata skor BMD pada subjek dengan asupan vitamin $C$ baik adalah 0,36 poin lebih tinggi dibandingkan dengan subjek yang asupan vitamin C kurang. Namun demikian, perbedaan ini tidak signifikan berdasarkan uji $t(p>0,05)$. Tidak signifikannya hubungan ini disebabkan karena vitamin $\mathrm{C}$ tidak secara langsung memberikan efek kepada BMD dan vitamin $\mathrm{C}$ bukan merupakan faktor tunggal yang berperan terhadap peningkatan dan penurunan BMD.

Vitamin C merupakan kofaktor penting untuk pembentukan kolagen dan sintesis hidroksiprolin dan hidroksilisin. Vitamin C juga mampu merangsang aktivitas alkalin fosfat sebagai penentu pembentukan osteoblas. Dengan demikian vitamin C merupakan komponen organik pada tulang untuk perubahan-perubahan sel dan pembentukan matriks tulang baru. Namun begitu, vitamin C tidak bekerja sendiri tetapi dibantu oleh vitamin $\mathrm{D}$ dan $\mathrm{K}$. Vitamin $\mathrm{K}$ dibutuhkan untuk sintesis osteokalsin yang berperan penting pada struktur protein 
dalam matriks tulang. Selain itu, vitamin $\mathrm{C}$ juga berperan sebagai antioksidan untuk melindungi jaringan-jaringan penghubung tulang dari bahaya radikal bebas.

Ketidakcukupan asupan vitamin C kadang-kadang tidak langsung memberikan efek negatif pada BMD terutama pada orang-orang yang menjalankan latihan olahraga secara teratur. Penelitian di bidang biokimiawi menunjukkan bahwa latihan fisik teratur dapat menurunkan tingkat stress sehingga bahaya radikal bebas yang akan merusak jaringan-jaringan penghubung tulang dapat dikurangi. Penelitian di bidang klinik juga menunjukkan bahwa aktivitas beban mempunyai pengaruh positif yang lebih besar dan pengaruh ini bisa terus bertahan dalam jangka waktu tertentu di saat asupan zat gizi menurun (17).

Penelitian di Cambridge, ROYAUME-UNI menjelaskan bahwa asupan vitamin $C$ yang rendah (7-57mg) dihubungkan dengan percepatan kehilangan tulang (18). Namun percepatan kehilangan tulang ini dapat dipelihara dengan latihan fisik. Pada penelitian ini, ditemukan 53 subjek mempunyai asupan vitamin C sebesar 7-57 mg namun sebanyak $58,5 \%$ di antaranya mempunyai BMD normal dan $41,5 \%$ mempunyai BMD tidak normal. Penjelasan ini juga diperkuat oleh penelitian yang dilakukan di Kanada tentang peranan latihan fisik pada wanita muda untuk membangun kepadatan mineral tulang. Penelitian dengan disain kohort 7 tahun pada 142 orang wanita menyimpulkan bahwa peningkatan BMD terjadi pada subjek yang rutin melakukan latihan dan peningkatan yang terbesar terjadi pada subjek dengan latihan fisik intensitas tinggi (19). Sebaliknya, kecukupan asupan vitamin $C$ kadang-kadang juga tidak langsung memberikan efek positif pada BMD. Penelitian di Amerika melaporkan bahwa asupan vitamin $C$ tidak langsung memberikan efek terhadap BMD, namun jika vitamin C tersebut dikonsumsi bersamaan dengan terapi hormon akan terjadi hubungan yang positif antara asupan vitamin C, terapi hormon, dan BMD (20).

\section{Hubungan antara asupan kalsium (Ca) dengan densitas mineral tulang (BMD)}

Tidak satu pun subjek $(0 \%)$ dengan asupan kalsium baik memiliki BMD tidak normal. Sebaliknya, terdapat $41,2 \%$ subjek dengan asupan kalsium tidak baik memiliki BMD tidak normal. Berdasarkan uji Fisher's exact, perbedaan ini tidak signifikan $(p>0,05)$ (Tabel 2). RP tidak dapat dihitung karena ada tabel yang mempunyai nilai nol.

Berdasarkan uji korelasi spearman, tidak terdapat hubungan antara asupan kalsium dengan $\operatorname{BMD}(p=0,368)$. Rata-rata skor BMD subjek dengan asupan kalsium baik 0,97 lebih tinggi dibandingkan subjek dengan asupan kalsium kurang. Namun begitu, perbedaan ini tidak signifikan berdasarkan uji $t(p>0,05)$. Tidak terdapatnya hubungan ini karena adanya interaksi mineral lain yang terdapat dalam tulang serta efek dari latihan fisik yang teratur.

Penelitian di Israel menunjukkan bahwa rata-rata total asupan kalsium per hari orang Amerika adalah 692 mg (57,67\% AKG American Dietary Allowance) (21). Hasil tersebut sedikit lebih tinggi seperti dijelaskan oleh penelitian di Kanada bahwa tipe makanan western kaya protein dan rendah karbohidrat. Makanan berprotein cenderung mengandung kalsium tinggi, seperti susu, keju, es krim, dan sarden (22). Namun demikian, orang Indonesia ataupun orang barat memiliki asupan kalsium di bawah AKG sehingga dapat disimpulkan bahwa pada umumnya masyarakat tidak mengonsumsi kalsium sesuai dengan kebutuhan yang dianjurkan. Dilaporkan rata-rata asupan kalsium orang Kanada di bawah 1.000 mg per hari (9).

Kalsium (Ca) adalah satu dari beberapa mineral yang berperan dalam pembentukan tulang dan sebanyak 99\% kalsium di dalam tubuh berada di dalam tulang. Pada awal kehidupan, asupan kalsium yang cukup dapat mengoptimalkan puncak kepadatan tulang dan pada kehidupan selanjutnya dapat mencegah kehilangan tulang. Rendahnya asupan kalsium berpengaruh pada awal kepadatan tulang sehingga dapat mempengaruhi pertumbuhan selanjutnya serta percepatan kehilangan tulang. Penelitian di Italia menjelaskan bahwa penurunan pertumbuhan terjadi ketika mineral tulang menurun sampai dengan 30\% (17).

Pada penelitian ini, asupan kalsium yang rendah tidak diikuti dengan asupan fosfor dan protein yang rendah. Fosfor adalah mineral lain selain kalsium yang mengisi tulang, sedangkan protein berperan dalam absorbsi kalsium. Sebanyak $50 \%$ kalsium yang diserap oleh tubuh sebagian besar (40\%) terikat oleh albumin. Dari 97 subjek yang mempunyai asupan kalsium kurang, hanya 18 subjek $(18,6 \%)$ yang mempunyai asupan protein kurang dan 17 subjek $(17,5 \%)$ yang mempunyai asupan fosfor kurang.

Penelitian di Italia juga membahas tentang peranan kombinasi kalsium dan latihan fisik. Penelitian tersebut membandingkan 2 kelompok subjek yang sama-sama mengonsumsi makanan dengan jumlah kalsium cukup tetapi berbeda intensitas latihannya. Hasilnya menunjukkan bahwa pada kelompok yang aktif melakukan latihan fisik mempunyai kepadatan tulang lebih baik dibandingkan kelompok yang banyak menghabiskan waktu untuk istirahat. Dengan demikian, dapat disimpulkan bahwa latihan fisik lebih berperan penting dibandingkan asupan kalsium dalam menentukan kepadatan tulang (17).

Penelitian di Finlandia yang menjelaskan bahwa latihan dengan intensitas yang tinggi (kecepatan 3,9-5,3 g) pada wanita usia 35-40 tahun berhubungan positif dengan perubahan BMD di pinggul dan intensitas latihan dengan kecepatan 5,4-9,2 g berhubungan positif dengan BMD tulang belakang (23). Wanita yang aktif melakukan latihan fisik akan mempunyai peningkatan yang besar pada BMD 
(19). Namun demikian, jika intensitas latihan menurun, maka akan terjadi kehilangan tulang yaitu berupa BMD bukan ukuran tulang dalam waktu tiga tahun yang akan datang (23). Selain terjadi penurunan BMD, juga diikuti dengan penurunan bone mass content (BMC) (19).

\section{Hubungan antara asupan fosfor dengan densitas mineral tulang (BMD)}

Sebanyak 63,9\% subjek dengan asupan fosfor baik memiliki BMD yang normal, sedangkan subjek dengan asupan fosfor kurang hanya sebanyak 47,4\% yang memiliki BMD normal. Namun demikian, berdasarkan uji continuity correction hal ini belum menunjukkan hubungan yang signifikan $(p>0,05)$. Hasil analisis menunjukkan nilai RP sebesar 1,77 dengan IK 95\% melewati angka 1 yaitu 0,65 - 4,83 (Tabel 2). Hal ini berarti bahwa asupan fosfor yang tidak baik bukan merupakan faktor risiko terjadinya penurunan BMD. Berdasarkan uji korelasi pearson, tidak terdapat hubungan antara asupan fosfor dengan BMD $(p=0,146)$. Rata-rata skor BMD sebesar 1,02 poin lebih tinggi pada subjek dengan asupan fosfor baik dibandingkan dengan asupan fosfornya kurang. Berdasarkan uji t perbedaan ini signifikan $(p<0,05)$.

Pada penelitian di Kanada dilaporkan bahwa ratarata subjek mempunyai asupan fosfor di atas $700 \mathrm{mg}$ per hari $(741 \pm 535 \mathrm{mg}$ ) (24). Perbedaan ini diduga karena total asupan energi yang lebih tinggi yaitu $2.343 \pm 715$ kalori, sementara asupan energi pada penelitian ini adalah $1.547 \pm 212$ kalori. Asupan energi ini berhubungan signifikan dengan asupan fosfor yang tinggi. Kepadatan tulang rendah seringkali ditemui pada orang-orang dengan asupan energi rendah (13).

Berdasarkan penelitian-penelitian tersebut, dapat dijelaskan bahwa makin tinggi asupan energi seseorang, makin tinggi pula asupan zat gizi lain terutama fosfor dan protein. Hal ini disebabkan makanan tidak mengandung zat gizi tunggal tetapi zat gizi yang bermacam-macam. Fosfor banyak terdapat dalam makanan sumber energi seperti jagung kuning, tepung ketan, dan beras ketan hitam serta terdapat pula dalam makanan sumber protein yang juga mengandung energi dalam jumlah moderat seperti kacang kedelai, kacang hijau, tempe, dan tahu.

Berdasarkan analisis bivariat antara hubungan fosfor dengan BMD, dapat disimpulkan bahwa tidak terdapat hubungan yang signifikan antara asupan fosfor dengan BMD. Hal ini menjelaskan bahwa perlu adanya interaksi beberapa zat gizi yang berperan dalam BMD. Pada penelitian ini dapat dikatakan bahwa hanya asupan fosfor, vitamin $A$, serta rasio asupan kalsium dan fosfor saja yang baik, sementara asupan zat gizi yang lain dikatakan kurang.

Fosfor merupakan salah satu elemen pembentukan tulang karena dibutuhkan dalam proses mineralisasi tulang. Asupan fosfor memiliki peranan yang cukup penting dalam pembentukan tulang pada masa pertumbuhan. Kadar fosfat serum yang rendah akan membatasi pembentukan tulang dan proses mineralisasi tulang. Namun demikian, hanya sedikit bukti yang menunjukkan bahwa makanan dengan kandungan fosfor yang rendah berpengaruh terhadap kejadian rendahnya BMD, begitu pula dengan makanan tinggi fosfor yang tidak berpengaruh langsung terhadap kesehatan tulang (25).

Penelitian di Kanada menegaskan bahwa fosfor berhubungan signifikan dengan BMD jika dikonsumsi dalam jumlah yang cukup dan didukung oleh asupan protein yang moderat (1,2 g/kg BB), kalium (>100 mmol/ hari), serta asupan kalsium yang cukup yaitu lebih dari 1000 mg per hari (24). Pada penelitian ini, kecukupan fosfor tidak didukung oleh asupan protein yang moderat $(49,7 \mathrm{gr}$ atau $0,88 \mathrm{~g} / \mathrm{kg} \mathrm{BB})$ dan kalsium yang cukup (345,5 mg per hari). Protein juga merupakan bagian dari zat organik penyusun matriks tulang sebagai struktur dari kolagen dan berperan penting dalam memproduksi hormon pertumbuhan yang mengatur sintesis tulang (19).

\section{Hubungan antara asupan seng (Zn) dengan densitas mineral tulang (BMD)}

Sebanyak $75 \%$ subjek dengan asupan seng baik memiliki BMD normal, sedangkan pada subjek dengan asupan seng kurang hanya 60,2\% yang memiliki BMD normal. Namun demikian, berdasarkan uji Fisher's exact belum menunjukkan perbedaan yang signifikan ( $p>0,05)$. Hasil analisis menunjukkan nilai RP sebesar 2,16 dengan IK 95\% melewati angka 1 yaitu 0,22-21,49 (Tabel 2). Hal ini berarti bahwa asupan seng belum dapat disimpulkan sebagai faktor risiko untuk terjadinya penurunan BMD. Berdasarkan uji korelasi pearson, tidak terdapat hubungan antara asupan seng dengan BMD $(p=0,098)$. Rata-rata skor BMD pada subjek dengan asupan seng baik 1,26 poin lebih tinggi dibanding rata-rata skor BMD subjek dengan asupan seng kurang. Walaupun demikian, perbedaan tersebut tidak signifikan $(p>0,05)$.

Tidak signifikannya hubungan ini disebabkan banyaknya mineral lain dan vitamin yang berperan dalam pembentukan matriks tulang. Kekurangan persediaan zat gizi tertentu mengakibatkan penurunan pertumbuhan dan kepadatan tulang. Selain itu, latihan fisik yang teratur juga berpengaruh terhadap penundaan penurunan kepadatan tulang (17).

Seng dibutuhkan untuk aktivitas osteoblastik, sintesis kolagen, dan aktivitas alkalin fosfatase. Sebagai komponen dari sistem enzim, seng berperan dalam pergantian matriks tulang. Kekurangan seng mengakibatkan gangguan pertumbuhan tulang yang khas ditandai dengan penipisan dan penurunan semua bagian sel. Pembentukan tulang dihambat dan pemecahan tulang dirangsang oleh hormon paratiroid (20).

Penelitian yang dilakukan di Amerika membuktikan bahwa asupan seng yang tinggi sebesar 25 mg per hari berhubungan signifikan dengan peningkatan kepadatan 
mineral tulang dibandingkan dengan asupan seng yang hanya $8 \mathrm{mg}$ per hari. Pada penelitian ini, tidak satu pun subjek mempunyai asupan seng tinggi ( $\geq 25 \mathrm{mg}$ ) dan sebagian besar subjek (98\%) mempunyai asupan seng kurang dari atau sama dengan $8 \mathrm{mg}$, hanya 2 orang yang mempunyai asupan seng lebih dari $8 \mathrm{mg}$ yaitu masing-masing $8,4 \mathrm{mg}$ dan $8,8 \mathrm{mg}$. Penelitian klinik yang lain juga menunjukkan bahwa pemberian suplemen kalsium yang dikombinasikan dengan seng menghasilkan pembentukan tulang yang besar dibandingkan dengan suplemen kalsium atau seng saja. Pada penelitian ini, subjek tidak hanya mengalami defisiensi seng tetapi juga kalsium. Di antara 102 subjek, 98 subjek (96\%) mempunyai asupan seng kurang dan 93 subjek $(94,9 \%)$ mempunyai asupan kalsium kurang.

\section{Hubungan antara rasio asupan kalsium (Ca) dan fosfor (P) dengan densitas mineral tulang (BMD)}

Tidak satu pun subjek (0\%) yang mempunyai rasio asupan kalsium dan fosfor tidak baik memiliki BMD yang tidak normal. Sebaliknya, terdapat $40 \%$ subjek yang mempunyai rasio asupan kalsium dan fosfor baik memiliki BMD tidak normal. Berdasarkan uji Fisher's exact, perbedaan ini tidak signifikan ( $p>0,05)$ (Tabel 2). Berdasarkan uji korelasi pearson, tidak terdapat hubungan yang negatif antara rasio asupan kalsium dan fosfor dengan BMD $(p=0,966)$. Ratarata skor BMD pada subjek dengan rasio asupan kalsium dan fosfor baik lebih rendah 1,13 poin dibandingkan subjek dengan asupan tidak baik, namun hasil uji t didapatkan nilai $p>0,05$ yang berarti tidak ada perbedaan signifikan antara rata-rata BMD subjek dengan asupan baik dan asupan tidak baik. Tidak signifikannya hubungan ini disebabkan rasio asupan kalsium dan fosfor yang baik tidak didukung oleh asupan yang baik dari zat gizi lain.

Penelitian di Amerika melaporkan bahwa terdapat hubungan antara rasio asupan kalsium dan fosfor dengan BMD dan signifikannya hubungan ini didukung oleh cukupnya asupan kalsium, protein, fosfor, serta rasio kalsium dan protein (26). Pada penelitian ini, asupan protein dan kalsium kurang. Rasio kalsium dan fosfor saja atau protein saja tidak dapat mengoptimalkan skor BMD. Faktor pendukung lainnya terhadap kepadatan tulang adalah rasio kalsium dan magnesium. Ketika kadar magnesium di dalam darah menurun, kalsium akan dieksresikan untuk mempertahankan keseimbangan rasio kalsium dan magnesium (27). Kalsium dan fosfor merupakan mineral utama dalam ikatan hidroksiapatit, sehingga kedua mineral ini harus berada dalam jumlah yang cukup. Asupan kalsium dan fosfor harus berada dalam keadaan yang proporsional sehingga dapat menjalankan proses mineralisasi tulang (2). Rasio kalsium dan fosfor berperan lebih penting dibandingkan asupan kalsium ataupun asupan fosfor yang bekerja tunggal (26).

Secara keseluruhan dapat disimpulkan bahwa untuk mempertahankan BMD tidak hanya memerlukan pendekatan kalsium, fosfor, atau zat gizi yang lain saja. Sebagai implikasinya adalah semua zat gizi berperan penting dalam membentuk tulang yang sehat, selain sebagai pemenuhan kebutuhan zat gizi dan peningkatan proses distribusi mineral. Pada penelitian di UK dilaporkan bahwa zat gizi saling memberi kontribusi dan berperan penting terhadap kesehatan tulang yang bisa dijelaskan dengan adanya pengaruh dari keseimbangan asam basa (5).

Selain itu, dapat dijelaskan pula bahwa latihan fisik yang teratur berpengaruh terhadap pemeliharaan BMD dengan cara meningkatkan BMD serta mengurangi hilangnya jaringan tulang pada wanita-wanita muda. Pembentukan tulang mengikuti fungsinya, jika tulang diaktifkan akan memberi pengaruh pada bentuk, besar, dan ketebalan tulang (28).

\section{KESIMPULAN DAN SARAN}

Berdasarkan hasil analisis dapat ditarik kesimpulan bahwa tidak terdapat hubungan yang signifikan antara asupan vitamin $A$, vitamin $C$, dan kalsium, fosfor, seng serta rasio asupan kalsium dan fosfor dengan BMD. Ratarata skor BMD pada subjek dengan asupan vitamin A, C, kalsium, fosfor dan seng baik secara berurutan 0,35 poin, 0,36 poin, 0,97 poin, 1,02 poin dan 1,26 poin lebih tinggi dibanding subjek dengan asupan kurang. Rata-rata skor BMD pada subjek dengan rasio asupan kalsium dan fosfor baik lebih rendah 1,13 poin dibanding subjek dengan rasio asupan kalsium dan fosfor kurang.

Berdasarkan hasil penelitian ini disarankan agar Departemen Kesehatan RI sebaiknya dapat memberi prioritas penapisan osteoporosis yang tidak hanya diarahkan pada kelompok usia lanjut saja tapi juga pada kelompok dewasa muda (usia peak bone mass). Program penyuluhan gizi terutama dalam hal pemenuhan asupan mikronutrien (vitamin A, C, mineral kalsium, fosfor, seng serta rasio asupan kalsium dan fosfor) juga perlu dilakukan secara menyeluruh dan hendaknya diprioritaskan pada kelompok usia dewasa muda. Bagi peneliti berikutnya yang ingin meneliti antara hubungan asupan zat gizi dengan BMD, perlu memperhatikan disain penelitian yang mempunyai kekuatan lebih baik untuk menjelaskan hubungan antara variabel. Selain itu, pada penelitian yang menggunakan alat pengukuran BMD disarankan untuk menggunakan alat yang standar yaitu DEXA.

\section{RUJUKAN}

1. Departemen Kesehatan RI. 1 dari 3 wanita dan 1 dari 5 pria memiliki kecenderungan menderita osteoporosis. News Letter 2005; 9.

2. Anderson JB. Nutrition for bone health (krause's food, nutrition, and diet therapy) editor L Kathleen Mahan, Sylvia Escott-Stump WB. Philadelphia, Pennsylvania: Saunders company; 2000. 
3. Weaver CM. Calcium requirements of physically active people. Am J Clin Nutr 2000;72(2):579s-84s.

4. Susanti E, Pramantara IDP, Pangastuti R. Asupan kalsium, vitamin D, kafein, merokok, indeks massa tubuh dan hubungannya dengan kejadian osteoporosis pada pria di Kecamatan Duren Sawit, Jakarta Timur. Jurnal Gizi Klinik Indonesia 2009; 6(2): 53-9.

5. Serfontein WJ. Osteoporosis : new perspectives. The South African Journal of Natural Medicine [serial online] 2005 [cited 2006 Jun 21]. Available from;http:// www.naturalmedicine.co.za/sajnm_main/article. php?story $=20030724105453400$

6. New SA, Robins SP, Campbell MK, Martin JC, Garton MJ, Bolton-Smith C, Grubb DA, Lee SJ, Reid DM. Dietary, influences on bone mass and bone metabolism : further evidence of a positive link between fruit and vegetable consumption and bone health. Am J of Clin Nutr 2000; 71(1):142-51.

7. Almatsier S. Prinsip dasar ilmu gizi. Jakarta: Gramedia; 2003.

8. UNICEF. Vitamin \& mineral deficiency, a global progress report; 2003.

9. Rebecca J, Bryant MS, Cadogan JO, Weaver CM. The new dietary reference intakes for calcium: implications for osteoporosis. J Am Coll Nutr 1999;18(90005):406S$12 \mathrm{~S}$.

10. Lwanga SK, Lemeshow S. Sample size determination in health studies, a practical manual. WHO: Geneva; 2005.

11. Sastroasmoro A, Ismael S. Dasar-dasar metodologi penelitian klinis. Jakarta : Sagung Seto; 2002.

12. Promislow JH, Goadman GD, Slymen DJ, Elizabeth BC. Retinol intake and bone mineral density in the elderly ; the Rancho Bernardo study. J Bone Mineral Res 2002; 17(8): 1349-58.

13. Sankaran B. Osteoporosis; clinical, radiological, histological, assessment and an experimental study. New Delhi, India: World Health Organisation; 2000.

14. Rejnmark $P$, Vestegaard $P$, Charles $P$, Hermann AP, Brot C, Eiken P, Mosekilde L. No effect of vitamin A intake on bone mineral density and fracture risk in perimenopausal women. Osteoporosis Int; 15 (11):872-80.

15. Johansson, Sara. Vitamin A and osteoporosis : experimental and clinical studies [dissertation]. Sweden: Upssala University; 2004.

16. Skelly, A. Too much vitamin A bad for bones. The Swedish Research, Medical post, Totonto [serial online] 2003 [cited 2006 Jun 21];39(7):21. Available from : http://proquest.umi.com/pqdweb?did=294971
$311 \&$ sid $=5 \& F m t=2 \&$ clientld $=58310 \& R Q T=309 \& V N a$ me=PQD.

17. Branca, F. Calcium, micronutrients and physical activity to maximize bone mass during growth. Rome, Italy: The National Institute of Nutrition; 1997.

18. Kaptoge S, Welch A, McTaggart, Mulligan A, Dalzell N, Day NE, Bingham S, Khaw KT, Reeve J. Effects of dietary nutrients and food groups on bone loss from the proximal femur in men and women in the 7 th and 8th decades of age. Osteoporosis Int; 14(5): 418-28.

19. Nicholson, P. Activity essential for young women to build bone mineral content. Medical Post, Toronto [serial online] 2006 [cited 2006 Jun 21];42(23):38. Available from: http://proquest.umi.com/pqdweb?ind ex $=0$ \&sid $=1 \&$ srchmode $=1 \&$ vinst=PROD\&fmt $=3$.

20. Wolf RL, Cauley JA, Pettinger M, Jackson R, Lacroix A, Leboff MS, Lewis CE, Nevitt MC, Simon JA, Stone $\mathrm{KL}$, Wactawski-Wende J. Lack of a relation between vitamin and mineral antioxidants and bone mineral density : results from the women's health initiative. Am J Clin Nutr; 82(3): 581-8.

21. Segal E, Dvorkin L, Lavy A, Rozen GS, Yaniv I, Raz B, Tamir A, Ish-Shalom S. Bone density in axial and appendicular skeletaon in patients with lactose intolerance : influence of calcium intake and vitamin D status. J Am Coll Nutr 2003; 22(3): 201-7.

22. MacDonald, Bishop H. Protein and calcium ; a winning combination. The Canadian Nurse 2003; 99(9).

23. Vainionpaa $R$, Korpelainen $R$, Vihriala E, Rinta-Paalova A, Leppaluoto J, Jamsa $\mathrm{T}$. Intensity of exercise is associated with bone density change in premenoupausal women. Osteoporos Int 2006;17(3):455-63.

24. Whiting SJ, Boyle JL, Thompson A, Mirwald RL, Faulkner RA. Dietary protein, phosphorus and potassium are beneficial to bone mineral density in adult men consuming adequate dietary calcium. J Am Coll Nutr 2002; 21(5):402-9.

25. Palacios, C. The role of nutrients in bone health, from A to Z. Crit Rev Food Sci Nutr 2006; 46(8):621-8.

26. Teegarden D, Lyle RM, McCabe GP, McCabe LD, Proulx WR, Michon K, Knight AP, Johnston CC, Weaver CM. Dietary calcium, protein, and phosphorus are related to bone mineral density and content in young women. Am J of Clin Nutr 1998; 68: 749-54.

27. Nordstrom A, Olsson T, Nordstrom P. Bone gained from physical activity and lost through detrai ning : a longitudinal study in young males. Osteoporosis Int 2005; 16(7):85.

28. Mangoenprasodjo, AS. Osteoporosis \& bahaya tulang rapuh. Yogyakarta:Think Fresh; 2005. 